\title{
On the Violence of Images and Image-Censorship in the Global Media: What can we learn from Schelling?
}

\author{
Katia Hay ${ }^{1}$ \\ University of Lisbon, Portugal
}

\begin{abstract}
The following paper presents a reflection on the violence of images understood as the "power" that certain images have in "provoking" what appear to be disproportionate responses on the part of the viewer. In particular, this paper addresses the systematic censorship of images (such as the photographs from David Jay's work. The SCAR Project) in open and highly mediatized societies that advocate and defend freedom of speech. But this requires a new understanding of the image and the working hypothesis of this paper is that we can find resources for this in the work of the philosopher Friedrich Wilhelm Joseph von Schelling.
\end{abstract}

Keywords: Censorship; Facebook; Image; David Jay; Media; Friedrich Wilhelm Joseph von Schelling; Susan Sontag; Violence of the image.

DOI: 10.22618/TP.PJCV.20193.1.192006

The PJCV Journal is published by Trivent Publishing

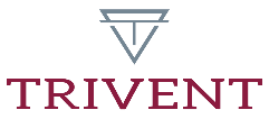

\footnotetext{
1 This paper was written while I was FCT Investigator, IF/01229/2015.

This is an Open Access article distributed in accordance with the Creative Commons Attribution Non Commercial (CC$B Y-N C$-ND 4.0) license, which permits others to copy or share the article, provided original work is properly cited and that this is not done for commercial purposes. Users may not remix, transform, or build upon the material and may not distribute the modified material (bttp:/ / creativecommons.org/ licenses/by-nc/4.0/)
} 


\title{
On the Violence of Images and Image-Censorship in the Global Media: What can we learn from Schelling?
}

\author{
Katia Hay ${ }^{1}$ \\ University of Lisbon, Portugal
}

\begin{abstract}
The following paper presents a reflection on the violence of images understood as the "power" that certain images have in "provoking" what appear to be disproportionate responses on the part of the viewer. In particular, this paper addresses the systematic censorship of images (such as the photographs from David Jay's work. The SCAR Project) in open and highly mediatized societies that advocate and defend freedom of speech. But this requires a new understanding of the image and the working hypothesis of this paper is that we can find resources for this in the work of the philosopher Friedrich Wilhelm Joseph von Schelling.
\end{abstract}

Keywords: Censorship; Facebook; Image; David Jay; Media; Friedrich Wilhelm Joseph von Schelling; Susan Sontag; Violence of the image.

[t] here is an aggression implicit in very use of the camera Susan Sontag, On Photography.

\section{Introduction: How to think about the violence of the image?}

It is not unusual to characterize Susan Sontag's book On Photography (1977) as an impressionistic, and in many respects problematic book. ${ }^{2}$ Years later Sontag herself would say, among other things, that it was "too conservative." 3 Despite all of this, though, it has the virtue of confronting us in a very moving and effective way with some of the most interesting and perhaps unanswerable questions regarding the nature of images. Most of all, it shows very clearly that what is at stake when discussing the violence of the image is always, more or less explicitly, the relation between images and reality. According to Sontag, "there is an aggression implicit in every use of the camera," because photographs "violate" the subject they depict, ${ }^{5}$ and they "imprison" reality. ${ }^{6}$ All in all, it seems, photographs do violence to reality in the sense that they intervene (in a presumably negative way) between us and our relation to the world. Echoing an old line of argumentation that we find already in Plato's rejection of the poets, it

\footnotetext{
1 This paper was written while I was FCT Investigator, IF/01229/2015.

2 See Darren Campion, “The Morals of Vision: Susan Sontag's "On Photography" Revisited” June 13, 2017), https://darrencampion.com/2017/06/13/the-morals-of-vision-susan-sontags-on-photography-revisited-part-1/\#_ednref1 (accessed March 5, 2019).

${ }^{3}$ Susan Sontag, "Looking at War," The New Yorker (December 2002),

https://www.newyorker.com/magazine/2002/12/09/looking-at-war (accessed April 7, 2019).

4 Susan Sontag, On Photography (New York: Picador, 1973), 7.

${ }^{5}$ Ibid., 14.

${ }^{6}$ Ibid., 9; 163.
} 
seems that Sontag's main claim is that images (photographs) are epistemologically and morally wrong: they deceive us and they anesthetize us, we become alienated from reality. ${ }^{7}$

Now, whether we agree or not with these claims, the pressing question is clear: what is exactly the relation between images and reality and how should we think about the violence of the image? Needless to say that the urgency to address these questions not only emerges from the way in which images are playing an increasing role in our daily experiences and interactions with the world (particularly evident in social media), but also from the fact that there seems to be no consensus as to how to deal with them and how much weight should be given to them. ${ }^{8}$ In this paper I argue that both questions are strongly intertwined, but I will begin by focusing on the latter.

What does it mean when we say that images are violent? Is it the content that is violent? - For sure, to focus on the "content" of the image is perhaps the most obvious way to think about the violence of images: Images are violent to the extent that they depict acts (or results) of violence. This approach, however, is not necessarily as straightforward and fruitful as it appears, precisely because it is based on the rather questionable presupposition that the relation between images and reality is that of representation or mimesis. But there are other ways - more interesting ways - to approach the problem. Sontag, like Marie-José Mondzain in her book L'image pent-elle tuer?, addresses the question in terms of freedom: images are violent to the extent that they deprive us of our freedom - our freedom to think and understand reality as it "really" is. In effect, according to Mondzain, any other way of thinking about the violence of the image would be inappropriate. And this means to say that the image as such cannot be considered violent. Or as she puts it: "the visible does not kill." In itself the image is nothing, it is only in our interaction with, and interpretation of the image that it becomes something, that it acquires a meaning, and it is only when we lose sight of this, when we become engulfed by the image, when the image consumes us, that we can talk about the violence of the image, or the violence of the visible. That is, the violence of the image is to be found and understood in the process whereby the distance between spectator and image (the distance that allows us to think) is annihilated: "the violence [of the image] resides in the systematic violation of the distance." 10 And this violence, she argues, is violence against the subject's ability to think critically - it is always a form of political violence.

One could also think of the violence of the image by referring to the way in which - as Sontag also points out - images (photographs and films in particular) have become "a useful tool of modern states in the surveillance and control of their increasingly mobile populations." 11 Indeed, since Sontag published her essays on photography this particular aspect has become an increasing concern for many authors and human rights activists, who describe our

\footnotetext{
7 “An event known through photographs certainly becomes more real [...] But after repeated exposure to images it also becomes less real" (Ibid., 19).

8 It is for instance a matter of debate to what extent photographs published on social media can and should be used as incriminating evidence in criminal investigations. An article from the New York Times from 2014 states that while there have been many cases "where social media has played an important role in serious criminal investigations," "prosecutors have also used Facebook pictures of people [...] even though such photos are often spoofs or playful posturing. And sexualized photos of women pulled from Facebook and MySpace have also been used repeatedly against women in child custody and divorce cases." See Ian Urbina, "Social Media: a Trove of Clues and Confessions," The New York Times (February 15, 2014), https://www.nytimes.com/2014/02/16/sunday-review/social-media-a-trove-ofclues-and-confessions.html (accessed April 2, 2019).

${ }^{9}$ Marie-José Mondzain, L'image peut-elle tuer? (Paris: Bayard, 2002), 63. All translations from French are mine.

${ }^{10}$ Ibid., 63.

${ }^{11}$ Susan Sontag, On Photography, 5.
} 
present as a time of "mass surveillance." But arguably, the fact that images can and are effectively used as a tool to exercise control over (specific or not) individuals and/or groups does not necessarily mean that this is something intrinsic to images. In fact, the data that is recorded by governmental surveillance programmes include not only photographs and videos, but also location and movements, calls, text messages, web-browsing activities etc.

In contrast to these approaches, but not necessarily opposed to them, I propose to reflect upon the violence of the image by considering what I would describe as unmeasured or disproportionate, i.e. "violent" responses to images on the part of the viewer(s). In other words, in terms of what an image can provoke in us, rather than in terms of what an image depicts or how it can or is de facto used. To be sure, to ascribe this kind of power to the image, to assume that an image is able to provoke anything is not unproblematic. As we have seen above, images in themselves are notbing, images do not do anything, they do not even mean anything in themselves, so to say. But the fact that we are active in our perception and understanding of images does not necessarily entail that we are not affected by images in ways that escape our control and comprehension (even if we subscribe to the idealist principle that esse est percipi: "to be is to be perceived"). Indeed, despite all our presumable autonomy of reason and distanced faculty of judgment and interpretation, images unconsciously and probably also unwantedly do affect us. As Rancière puts it in relation to the aesthetic experience: "The "free appearance" [i.e. the work of art, or the image in this case] stands in front of us, unapproachable, unavailable to our knowledge, our aims and desires." 12 And what is more, the fact that we sometimes respond in inexplicable ways to images seems to indicate that there is a lack of a satisfying theoretical understanding of images and their meaning and role in our lives.

The aim of this paper is to shed some light on what seem to be violent reactions to images. At the same time, I will argue that these violent, i.e. disproportionate responses (such as image-censorship) urge us to rethink our understanding of the image in a way that enables us to make sense of those apparently incomprehensible or disproportionate responses. In the last part of this paper I will show how re-reading and re-interpreting some of Schelling's most fundamental claims in his Philosophy of Art can help us overcome what seems to be a failure in our understanding of the nature of the image, its "violence" and relation to reality.

\section{Image-Censorship}

\section{Ultimately, these images were not taken down because we were "nude," but because we challenged a system and made people uncomfortable.}

So, what are unmeasured, i.e. violent responses to images? - One could consider different cases of disproportionate responses to images. This paper focuses on what seems to be the most radical response to an image, namely its annihilation, elimination or exclusion, that is to say: image-

\footnotetext{
12 Jacques Rancière, Dissensus. On Politics and Aesthetics (London and New York: Continuum, 2010),117. The specific context of this quote is an analysis of Schiller's Über die Ästhetische Errziebung des Menschen. Of course, the difference between Rancière's position here and the position described above held by Mondzain is that for Rancière we are, it seems, always powerless vis a vis the image, whereas for Mondzain it is only when we are deprived of the necessary distance to interpret it critically.

${ }^{13}$ Jillian C York, "When it comes to nudity, Facebook is little different than Victorian England," The Guardian (July 9, 2015), https://www.theguardian.com/technology/2015/jul/09/Facebook-nuditypolicy-censorship-freedom-of-expression (accessed February 12, 2019).
} 
censorship. More specifically I will focus on image-censorship within social media platforms such as Facebook or Twitter. ${ }^{14}$

In May 2018, Amal Fathy (a human rights activist based in El Cairo) was arrested for posting a video on Facebook in which she shared her experience of sexual harassment and criticized the Egyptian's government inaction. Seven months later, Fathy was released and put under house arrest. ${ }^{15}$ As has been pointed out by Amnesty International, "political regimes and cultures that do not uphold the principle of freedom of speech are becoming increasingly threatened by the power of social media to influence, giving rise to endless arrests, detentions, internet shutdowns and social media taxes" - not to mention censorship. ${ }^{16}$ Now, however these cases may concern us, the truth is that it seems hardly surprising that more or less totalitarian regimes would use censorship as a means to control their citizens - be it of images, texts, internet sites or films.

What does not appear so easy to understand is image-censorship in countries that are committed to democratic values and human rights, freedom of speech and free press, and where censorship seems so difficult to enforce, if not futile (especially in the case of images). And yet, despite the fact that globalized media have made censorship increasingly complicated, ${ }^{17}$ images are being censored regularly - be it by governments (e.g. the US and UK governments censoring images of soldiers torturing prisoners in Iraq), social networks (such as the case of personal photographs being censored on Facebook and Twitter), or the so called "self-imposed" censorship of war images by professional journalists. ${ }^{18}$ (And these are the cases in which censorship has failed, for otherwise we would not know about them.) There is in effect a significant discrepancy ${ }^{19}$ between the feeling the average internet user has of an unlimited access to images and information in public and social media, on the one hand, and the reality of media censorship, on the other.

Unsurprisingly, most scholars addressing these issues argue that the problem of censorship in the media is of extreme importance. ${ }^{20}$ On the whole, however, they tend to approach the problem of media-censorship, including image-censorship, in relation to questions regarding freedom of speech and free press ${ }^{21}$ or freedom in general. ${ }^{22}$ It is thus always a question of determining whether or not certain forms of censorship are necessary, and how mediacensorship interferes with free speech and what has been described as our "duty"/"right" as

\footnotetext{
${ }^{14}$ In previous workshops I have also investigated the responses that were provoked by the diffusion of Alice Seeley Harris' photographs of the atrocities committed under the rule of King Leopold in the Belgian Congo. Alice Harris would be described as the "lady who brought down a King."

${ }^{15}$ Associated Press, "Egyptian sexual harassment activist Amal Fathy released," The Guardian (December 27, 2018), https://www.theguardian.com/world/2018/dec/27/egyptian-sexual-harassment-activistamal-fathy-released (accessed February 12, 2019).

16 “The Rise of Social Media Censorship," Amnesty International UK (July 26, 2018), https:/ /www.amnesty.org.uk/blogs/ether/rise-social-media-censorship (accessed February 12, 2019).

${ }^{17}$ See Nicholas Mirzoeff, An Introduction to Visual Culture (London/New York: Routledge 1999).

${ }^{18}$ See for instance, Clay Calvert \& Mirelis Torres, "Staring Death in the face During Times of War: When Ethics, Law, and Self-Censorship in the News Media Hide the Morbidity of Authenticity," Notre Dame Journal of Law, Ethics \& Public Policy 25/1 (2012): 87-122.

19 This discrepancy would in fact be worthy of a much deeper analysis than the limits of this paper allows me.

${ }^{20}$ See for instance, Timothy Garton Ash, Free Speech: Ten Principles for a Connected World (London: Atlantic Books, 2016) \& Marc Höchli, The Invisible Scissors: Media Freedom and Censorship in Switzerland (Bern: Peter Lang, 2010).

${ }^{21}$ See David V. Ward, "Philosophical Issues in Censorship and Intellectual Freedom," Library Trends 39/1-2 (1990): 83-91; Martin Baker \& Julian Petley, III Effects: The Media/Violence Debate (London: Routledge, 2001).

22 See Marie-José Mondzain, L'image peut-elle tuer?
} 
citizens to be properly informed. ${ }^{23}$ In August 2018, a polemical and rather obnoxious character from the US, who was known for sharing misinformation and promoting violence, was banned from several social platforms, such as Facebook and YouTube, on the grounds that he was undermining the very principles of democracy that enabled him to share his views. Needless to say, this move was not uncontroversial. ${ }^{24}$ However, this case of censorship polemical as it is $-{ }^{25}$ seems to be relatively straightforward: the user's "toxic brew of lies, hate and product placement" was banned from several platforms, allegedly because it was considered a threat to democratic values. ${ }^{26}$ But, there are many examples, especially when it comes to image-censorship within social networks such as Facebook or Twitter that are not in any way as straightforward as this case. And what is more, they become all the more puzzling and therefore interesting (at least from a philosophical point of view) the moment we consider the arguments given by the censors themselves. In fact, when we listen to the justifications given for image-censorship we cannot help asking ourselves what exactly is being censored and why.

Typically, the reason for censoring images (when it is not a legal issue) concerns "national security" or the alleged violence, nudity and/or sexual content of the images (presupposing that these images in some way promote the same violent or obscene acts that they show). In other words, censorship is somehow always intertwined with politics and/or sexuality, power and taboo, or as Foucault puts it: "the regions where the grid is tightest [namely, $\mathrm{KH}$ ] those of sexuality and politics" ${ }^{27}$ In many cases, though, this rationale proves to be totally unjustified, once we take into account that there are still many images - arguably even more "violent," "obscene" or "indecent" than those censored - which we can access without any restrictions, even within the same media-platforms issuing the censorship. This is particularly obvious in the cases of the censorship in Facebook and Twitter of images of women breastfeeding and images of women's breasts after having suffered a mastectomy, such as the photographs from David Jay's work The SCAR Project (see figs. 1-3). ${ }^{28}$ It goes without saying that these acts of censorship of women breastfeeding, in which mothers were told they had posted photographs containing "sexual exploitation of minors," 29 have been the origin of numerous responses and online protests.

${ }^{23}$ See R. George Wright, "Self-censorship and the Constriction of Thought and Discussion under Modern Communications technologies," Notre Dame Journal of Law, Ethics \& Public Policy 25 (2011): 123-142. As Francis Fukuyama has recently argued, social media platforms face today an "acute dilemma" "in reconciling their commitments to both freedom of speech and to social responsibility toward the democracies that shelter them." See Francis Fukuyama, "Platform or Publisher? Social Media and Censorship," The American Interest (August 8, 2018), https:/ /www.the-american-interest.com/2018/08/08/social-media-and-censorship/ (accessed April 7, 2019).

${ }^{24}$ See Julia Carrie Wong \& Olivia Solon, "Does the banning of Alex Jones signal a new era of big tech responsibility?," The Guardian (August 10, 2018),

https://www.theguardian.com/technology/2018/aug/10/alex-jones-banning-apple-Facebook-

Youtube-Twitter-free-speech (accessed March 20, 2019).

${ }^{25}$ Fukuyama's almost immediate reaction was both of approval and critique. See "Platform or Publisher? Social Media and Censorship."

${ }^{26}$ See Julia Carrie Wong \& Olivia Solon, "Does the banning of Alex Jones signal a new era of big tech responsibility?" Another interpretation also suggested in this article from The Guardian is that Facebook was forced to do this because it could not sustain the contradiction any longer of not censoring this kind of users on the grounds of free speech, while it was de facto censoring so many other users and images, which were clearly much less "dangerous."

${ }^{27}$ Michel Foucault, L'ordre du discours (Paris : Gallimard, 1971), 11. Foucault says this in relation to discourses ("the prohibitions that surround it [discourse] very soon reveal its link with desire and with power", 12).

${ }^{28}$ See the website: www.davidjayphotography.com (accessed January 8, 2019).

${ }^{29}$ Reported by a Facebook user. 


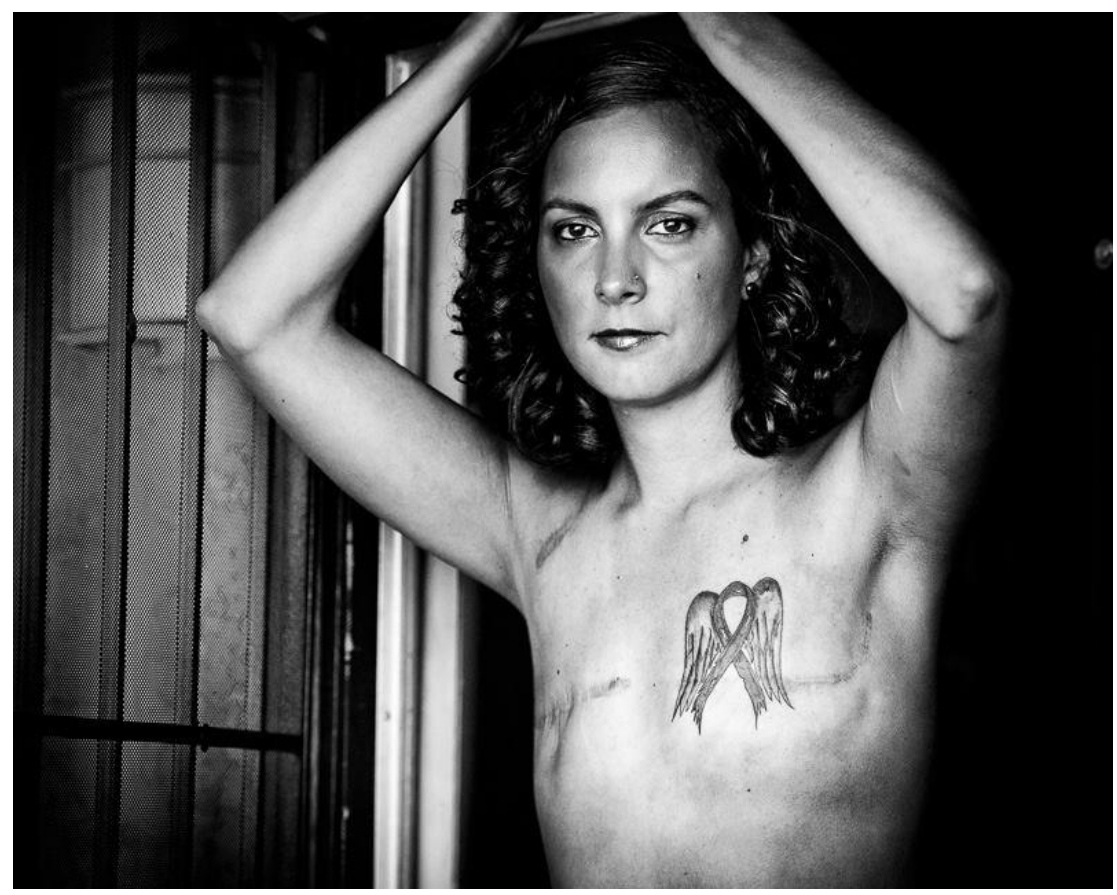

Fig. 1. David Jay, The SCAR Project. Breast Cancer Is Not A Pink Ribbon. Copyright 2011 (C) David Jay Photography.

Censorship of images on Facebook is the result of a combination of Facebook censors, private users denouncing images and algorithms. In other words: the procedure is completely untransparent and has given rise to many criticisms. To be sure, as a private company, Facebook has no obligation to publish anything it does not want to. But following Fukuyama, one can argue that, given their scope, ${ }^{30}$ social media platforms such as Facebook or Twitter have become "something like a monopoly supplier of social media services," which means that it is "difficult to see their acts of "censorship" as unimportant or "private" in a strict sense." In other words: "Facebook today exercises government-like powers of censorship despite the fact that it is a private company," 31 its doings and un-doings cannot be perceived as a private affair only. On the other hand, whether we accept this argument or not, the fact is that Facebook still feels compelled to justify and explain its acts of censorship. It has a certain "image" or "morale" it wants to "sell." In this way, Facebook assures users that they censor all images containing nudity and/or sexual obscenities. But here is where the inconsistencies begin - for how could the nudity of women breastfeeding or of women with scars on their breasts be a reason for censorship, while there are so many other images (from advertisements to personal photographs) where the sexual content is much stronger and the nudity and/or violence arguably more explicit than in the former? Not to mention the fact that male nudity is by far more tolerated than female nudity: male nipples are accepted whereas women's nipples are systematically censored (from the two images below from David Jay's SCAR Project only the first was censored).

\footnotetext{
${ }^{30}$ Facebook has now over 2,2 billion users around the world

${ }^{31}$ See Francis Fukuyama, "Platform or Publisher? Social Media and Censorship."
} 


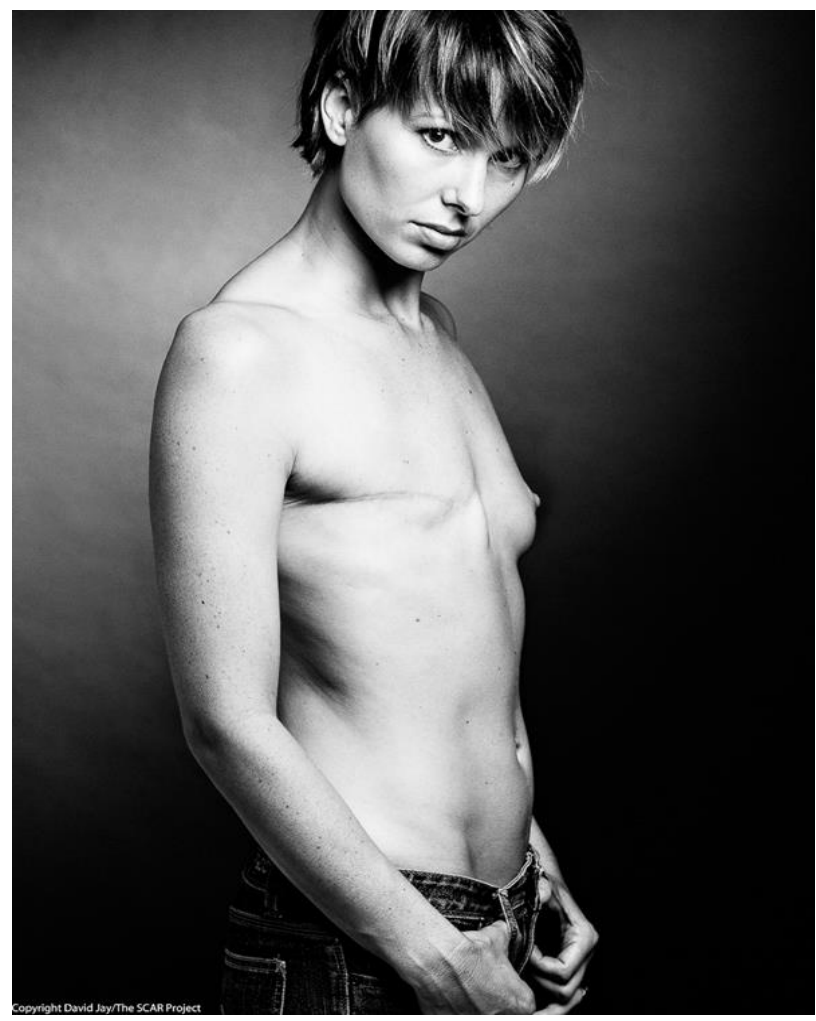

Fig. 2. David Jay, The SCAR Project. Copyright 2011 @ David Jay Photography.

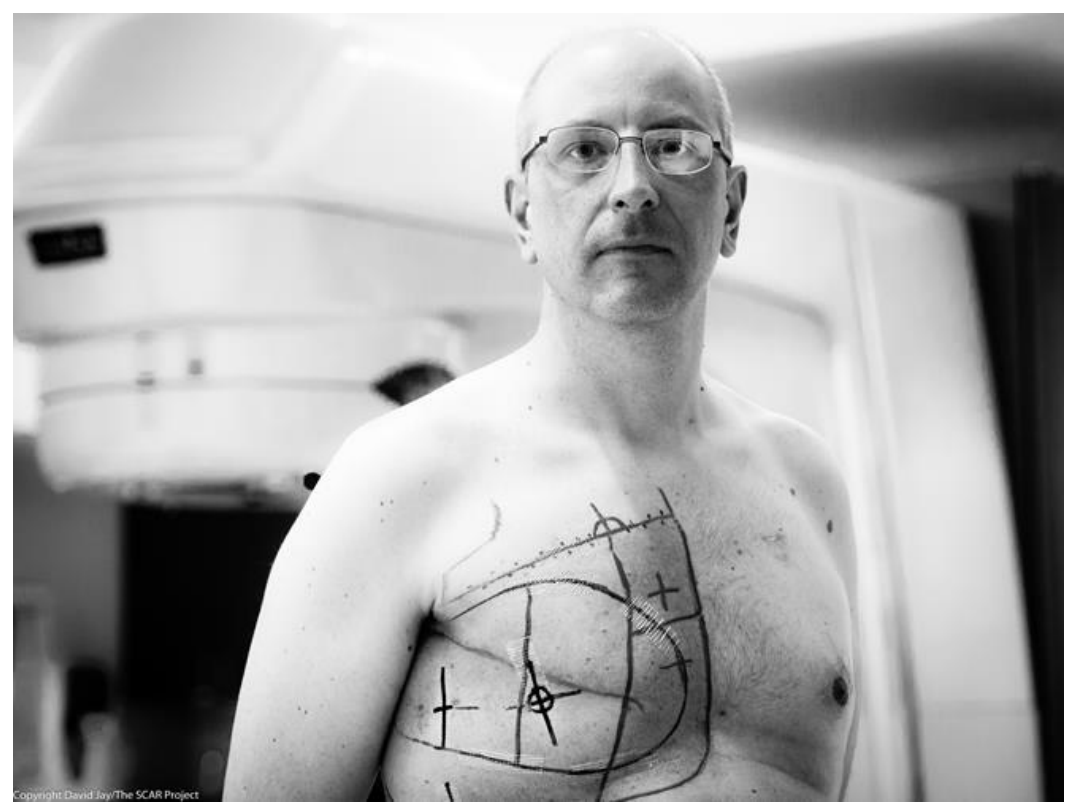

Fig. 3. David Jay, The SCAR Project. Copyright 2011 @ David Jay Photography. 
The fact that these justifications and explanations do not really explain anything seems to indicate that if those images were censored, it had to do with something other than what was represented in them, and for reasons that go in some sense beyond the alleged nudity displayed by them. In other words, the reason why these explanations are unsatisfactory has to do with their presuppositions, namely the belief that images are censored because of their content. And this ultimately means that, contrary to our initial assumptions, there is something that images do that cannot simply be described in terms of what the image contains; nor can it be reduced to the viewer's inability to maintain a healthy distance from the image in order to preserve her freedom and critical judgement. But if censorship is not simply a matter of what is represented (acts of violence or sexually explicit content) bow else can we account for the "power" of certain images, images so powerful or violent that they provoke acts of censorship on the part of public media or state security organs?

Indeed, it is clear that in order to understand image-censorship in the global media, in order to understand what it is that is actually been censored we need to rethink the nature and meaning of images. And this means also, to find new ways of understanding the relation between images and reality. To be sure, this project is not in itself new: the literature on questions about the image and its relation to reality is so vast as to be almost unfathomable. But if the foregoing argumentation is correct, our understanding of the image must also be able to account for violent responses, such as censorship. Applying Foucault's argument for discourse-analysis to images in the media, ${ }^{32}$ we could say that we have to be able to explain images in a way that includes considering that censorship, prohibition and omission are never contingent matters, but rather belong to the logic of the ways in which reality is understood, controlled, modified and constructed. In this sense, it is not so much about discovering secret intentions and denouncing manipulative authorities; rather, it is a matter of understanding images and the logic that structures and organises them (including absences and exclusions), as well as the ways in which they relate to and inform the reality we inhabit, our identities and self-understanding by asking ourselves: What does the exclusion/censorship of an image say about the kind of 'power' that we as spectators bestow on images? What does it say about what they do, about their function in our relation to and construction of reality? ?3 $^{33}$

The following section is an attempt to address these questions by recurring to some of Schelling's thoughts in his Pbilosophy of Art. The ambition, however, is to see whether Schelling can help us to open up a new way of approaching these questions rather than giving definitive answers.

\footnotetext{
32 See Michel Foucault, L'ordre du discours.

${ }^{33}$ For sure, the power (or violence) of images and their relation to reality is not a new one. Authors such as Jean-Luc Nancy, The Ground of the Image (New York: Fordham University Press, 2005); Georges DidiHuberman, Ce que nous voyons, ce qui nous regarde (Paris: Les éditions de minuit,1992); Marie-José Mondzain, L'image peut-elle tuer ?; Patrick Fuery \& Kelly Fuery, Visual Culture and Critical Theory (London Arnold Publisher, 2013); or Gertrud Koch, "Image Politics: The Monotheistic Prohibition of Images and its Afterlife in Political Aesthetics," Critical horizons 14/3 (2013): 341-354, to name a few have asked similar questions, but they do not focus on image-censorship and, on the whole, the questions remain unanswered.
} 


\section{On the relation between images and reality}

The fact that representational theories of the image are problematic, the fact that images cannot be analysed merely in terms of their content, that images are not copies of reality, is nothing new - at least not since 19th century thought in philosophy, aesthetics and the history of art. And yet, most studies dedicated specifically to image-censorship treat images as pieces of information or "snapshot[s] of the truth" 35 - representing something of reality in ways that words cannot do. Now, one of the main problems with this position is that the spectator (or spectator-philosopher) is always in a position to establish (even if only theoretically) whether a given image is true or false by referring to the "reality" that is represented in the image. That is to say, this position relies on our ability to step outside the virtual world of images and to evaluate them against the "real" world, which, in contrast, is implicitly conceived of as an image-free reality to which we presumably have direct and unmediated access. This theory, thus, does not allow us to consider the many different ways in which our very perception of 'reality' may be affected, influenced and of course mediated by images. It does not enable us to even consider the power that images may have on our own understanding, evaluation and construction of that presumably univocal "reality." And, as was already noted above, this theory does not really enable us to understand why certain images are censored for being violent/obscene, while others that show the same or even more violent/obscene content are not.

At the same time, on the other side of the spectrum so to say, authors inspired by more postmodern approaches, argue that the process of globalization and the development of the media, the massive propagation of images through television and internet, have made it impossible for us to disentangle ourselves from the virtual reality of the media, so that it makes no sense to think in terms of an opposition between the real and the virtual/copy/fiction. Immersed in a virtual world of images, we can no longer distinguish between the real and the imaginary, between truths and lies. Or, in Baudrillard's terms, we are trapped in the simulacrum and we have no way of distinguishing between images and the real. As he argues in his book Simulacra and Simulation, in our present mediatized societies we are no longer able to refer to anything real, the result being that images themselves have lost their representative value; they are meaningless and refer to nothing but themselves: they are self-referential. ${ }^{36}$ From this perspective it would seem that we have gradually become immune and insensitive to any effects images may have had on us.

Appealing as they may be, though, these postmodern approaches are also unable to account for the fact that in highly mediatized societies, images are nevertheless constantly being censored. Indeed, while the first position relies on our capacity as rational beings to see through the whole alienating process of global media, and evaluate it in relation to a putative "objective reality," the second position takes the failure of reason and the failure of the Enlightenment project (reason will liberate us from all forms of lies, superstitions etc.) as a matter of fact. And yet, in the end, both positions seem to have the same outcome, for they both make any real analysis of the effect of images impossible: the first position fails to see that our sense of reality may be thoroughly mediated by the images we are constantly exposed to, and the

\footnotetext{
34 This is the text of a street graffiti in Miami from January 2014, composed of a pink background with the sentence in black print running diagonally. See $:$ http://seanwashere.com/photo/ill-see-believe-miami-street-art/ (accessed February 20, 2018).

35. Clay Calvert \& Mirelis Torres, "Staring Death in the face During Times of War: When Ethics, Law, and Self-Censorship in the News Media Hide the Morbidity of Authenticity" : 93; 113

36 Jean Baudrillard, Simulacres et simulation (Paris: Galilée, 1981), $16 \mathrm{ff}$.
} 
second denies the possibility of us ever being able to evaluate the way in which images affect us. In other words, neither of these positions enables us to understand the problem of the censorship of images and to raise the question: why do certain images provoke these kinds of reactions? How do images affect us? What role do they play in our understanding/construction of reality?

In a sense, both of these positions depend on the distinction between reality and virtuality (even if it is to deny the possibility of this distinction); they both work with the idea that the appropriate way to analyse images is by considering them in relation to what they represent (even if it is to say that representation is impossible). Now, what is surprising about this is that, as mentioned above, representational theories have been contested at least since the 19th century; both theoretically (F.W.J. Schelling, A.W. Schlegel, Nietzsche, Freud, Benjamin, Adorno or Derrida, to mention a few) and in practice (Romanticism, Expressionism, Cubism, Surrealism, etc.). And yet, it is only relatively recently that theorists have considered contesting common-sense representational views of the photographic images we nowadays encounter in the media on a regular basis. Even authors who develop critical theories on photography stress its representational character, the general assumption being photographs, or rather cameras "record" reality. ${ }^{37}$ This is certainly related to the fact that photographs (especially journalistic and personal photographs) are usually not taken to be works of art. But it also seems to be a way of avoiding the challenges of determining the specific role(s) that images play in our own constructive relation to and understanding of reality.

To make matters even more confusing, although the positons described above represent two opposing views, it is not uncommon to try to reconcile both (for they both "ring true"). But this does not come without contradictions and inconsistencies. In a way this is what is going on in Sontag's book from 1977. Here, one of the main problems that Sontag addresses is precisely the relation between images (photographs) and reality. And although towards the end of her last essay she argues that " $[\mathrm{t}]$ he powers of photography have in effect de-Platonized our understanding of reality, making it less and less plausible to reflect upon our experience according to the distinction between images and things, between copies and originals," and insists that "the force of photographic images" derives from their ability to turn reality "into a shadow," and that "[i]mages are more real than anyone could have supposed," 38 her analysis of photography is largely based on a clear distinction between reality and images. For instance, she writes: "Photographs are a way of imprisoning reality"; 39 or: "although there is a sense in which the camera does indeed capture reality [...] photographs are as much interpretation of the world as paintings and drawings." 40 But then, she also says that photographs reproduce the world "as it looks." 41 Thus, in the end, what seems to be a relative straightforward and uncontroversial distinction between reality and photographs gradually becomes the source of theoretical inconsistencies that make it very difficult to know what, according to Sontag, a photograph/image really is. ${ }^{42}$

\footnotetext{
${ }^{37}$ Susan Sontag, On Photography, 23. Another good example would be Roger Scruton's paper "Photography and Representation" published in Critical Inquiry, where he criticizes the notion of "representation" only to undermine the intentional character of photography and to affirm that what is interesting about a photograph is that it is a record of bow an actual object looked like. See Roger Scruton, "Photography and Representation," Critical Inquiry 7/3 (1981): 577-603.

38 Susan Sontag, On Photography, 179-180.

39 Ibid., $163 \mathrm{ff}$.

${ }^{40}$ Ibid., 7.

${ }^{41}$ Ibid., 23.

${ }^{42}$ In her subsequent writings on photography and images of war, Sontag criticized many of her views, but did not develop a clear position regarding the relation between images and reality.
} 
Sontag describes rather negatively the way in which photographs have become something like "the device that makes real what one is experiencing" - the underlying criticism being that we now seem to prefer or give more importance to the image than to the experience itself (here Sontag mentions tourists with their cameras). To be sure, from this perspective, the massive proliferation of images we are witnessing at present is perceived and denounced as a lack, an impoverishment of our relation to the world, to what she calls "experience." And in the end, this whole view will lead Sontag to adopt a position of criticism (even if it's very tamed) towards images. ${ }^{43}$

To be sure, there is a sense in which one can relate to what she is saying. But there are also rather problematic assumptions regarding the nature of and relation between images and reality, which I believe can be illuminated by referring to Schelling's theoretical approach. For, in a certain way, Schelling's entire philosophy can be seen as a constant engagement with the problem of understanding the relation between the real and the ideal. Both "realms" are identical and different at the same time.

In very general terms, the way in which Schelling solves this problem is by affirming that both the "real" and the "ideal" are expressions of what he calls "the absolute." That is: both a "tree" and an "image of a tree" are different forms through which "the absolute" manifests itself. They are ontologically equivalent, and both participate in our understanding of the world and of ourselves. And this has two important consequences for Schelling's aesthetic theory from 1803 that are particularly helpful in rethinking the question of the image, which we will see in more detail below: images do not duplicate reality, and hence, we cannot meaningfully analyse them in terms of what they represent.

\section{Schelling and the violence of image}

If we agree with the idea that there is something wrong about thinking that "photographs" or images "make an experience real" (as Sontag suggested) it is because (1) we believe that a photograph is less real than an experience; and (2) we believe that the experience is, so to say, the "real thing." In other words, we ascribe a degree of reality to things (under the rubric: copies are less real than originals), which in the first instance seems unproblematic. But the problem is that, by doing so, we are in some way assuming that through our own experiences we have immediate access to reality, or what is more: we assume that what is real is our experience (i.e. our experience of the world, our experience of reality). In other words, by problematizing the way in which images relate to reality we tend to de-problematize the way in which we relate to reality and the way in which we talk or refer to "reality." It seems, thus, that where Sontag sees two opposites (images-reality), we should be seeing a triad: (1) there are images, (2) experiences, and then (3) there is reality, or "the real" (in order to avoid confusion). This is what in more Schellingian terms we would call the absolute. For we mean different things by "reality" when we say for instance "images are copies of reality" and when we say "we do not have access to reality." While in the first case the assumption seems to be that 'reality' can be perceived and comprehended by us, in other words 'reality' is what appears to us, in the latter case "reality" seems to refer to a deeper level of "reality" that always necessarily remains

\footnotetext{
${ }^{43}$ One might even argue that her position leads to a certain form of censorship or self-censorship, as she writes at the end of one of her essays: "And just because they are an unlimited resource, one that cannot be exhausted by consumerist waste, there is all the more reason to apply the conservationist remedy. If there can be a better way for the real world to include the one of images, it will require an ecology not only of real things, but of images as well." This view in particular is one she would later strongly criticize in her essay "Looking at War," published in The New Yorker in December 2002.
} 
hidden and unknown. Sontag's text seems to use both as if they were synonyms, which makes her understanding of the relation between images and reality somewhat difficult to grasp.

The advantage of Schelling's philosophy, and his philosophy of art in specific, is that it enables us to make these distinctions, without having to abandon the insight that images have a specific relation to reality, but one that is not of mimesis. In other words, we do not need to refer images to our perceptions, feelings and understandings of reality or the way in which the world appears to us (what Sontag calls experiences), because both "images" and "reality" (as it appears to us) are, in different ways, manifestations or expressions of the same (i.e. the same force, the same movement, the same absolute). Conversely, the existence of images, the fact that images are the medium of the absolute, from a Schellingian perspective does not mean that reality itself has evaporated in the ocean of the media (where everything is medium, but nothing more); instead it forces us not only to realize that images are never to be understood as a duplicate of the reality we perceive and experience, but also to rethink what is specific about images, what they tell us about ourselves, about that "force" or "absolute" as well as our relation to it.

According to Schelling, the image shows or points towards, it incarnates something that is "bigger" and that somehow goes beyond the elements composing it or depicted in it. This something that is "bigger" is what Schelling calls the absolute (and also God), and is to be understood as the totality of everything that is; the world, the universe. ${ }^{44}$ The term Schelling uses for this specific form of becoming manifest through images is "darstellen" (to present or represent). One might object that Schelling has merely transferred the problem of representation to another realm: instead of representing a specific thing from reality, art now represents something obscure and unknown: the absolute. But this is not necessarily the case. First, because what Schelling means by Darstellung is not that the work of art, the image in this case, refers to the absolute, but rather that it incarnates it, expresses it, he even says that "it is" the absolute..$^{45}$ It is the way in which the absolute manifests itself, becomes "real," graspable. What is important here is not the fact that some-"thing" is being shown, but the "being shown," the appearance itself. Secondly, and directly related to the former: the 'absolute' is not to be understood in any way as any-"thing" that we could actually refer to. The absolute is not a thing, but rather an activity (similar to the notion of nature in Spinoza or life in Nietzsche), namely the activity of self-affirmation (which he deduces from the notion of identity). As he writes in the first two paragraphs of his "Construction of Art as Such and in General" from his Lectures on The Philosophy of Art from 1803-4:

\1. The absolute or God is that with regards to which being or reality follows immediately
from the idea, that is, by virtue of the simple law of identity, or, God is the immediate
affirmation of itself
$[\ldots]$
To be real = to be affirmed [Realsein = Affirmiertsein]
$\$ 2$. God as the infinite affirmation of himself comprehends himself as infinitely affirming,
as infinitely affirmed, and as the indifference of both, though be himself is none of these
in particular.
$[\ldots]$

${ }^{44}$ See Friedrich Wilhelm Joseph Schelling, Darstellung meines Systems der Philosophie (1801), in Ausgewählte Schriften, Band. 2 (Frankfurt am Main: Suhrkamp, 1985).

${ }^{45}$ Schelling uses for this the notion of symbol. 
God is nothing as a particular; rather, what he is, he is only by virtue of infinite affirmation. Hence, God is understood as affirming himself, as affirmed by himself, and as indifference, only once again by means of the infinite affirmation of himself. 46

As mentioned already, the absolute cannot for Schelling be thought of as something above or outside the real world, something we could point towards with our fingers or identify with our thoughts. ${ }^{47}$ The absolute is (1) the totality of everything that is, i.e. every single manifestation of existence (including art, i.e. images), as well as (2) the very forces or desires that are bebind that, which is described here by Schelling in terms of an activity, namely the activity of being in the form of self-affirmation, and (3) the unity of both (being and becoming, or being and self-affirmation).

Now, if the essence of the absolute is to affirm itself and if at the same time the absolute is to be found also in every single form of existence, this means that images are one of the ways in which the absolute manifests itself, i.e. one of the ways in which it affirms itself. Or to put it differently we can say that the essence of the "absolute" is to produce images (of itself). But this means that images do not represent a particular thing, but instead must always be considered as a presentation (Darstellung) of the absolute itself, and hence, to a higher or lesser degree, ${ }^{48}$ of the totality of the universe, or if you like of the entire system to which these images and creation of images belong. Images mirror, or to be more precise images disclose the totality of the world as well as its constant necessity to affirm itself, i.e. to produce images of itself and present itself in images.

In this way, Schelling's analysis of the image enables us to think about the absence of referentiality (such as we find in Baudrillard) without proclaiming as a consequence the absence of meaning. For, the fact that images are not to be analysed in terms of their representational content does not mean that they have no content or that they are meaningless. On the contrary, it means that we need to rethink the way in which images are meaningful and powerful. Indeed, one of the main values of Schelling's theory - despite its somewhat outdated terminology and metaphysical taste - is that he does not negate the possibility of dealing with and understanding images. And in contrast to authors such as Nancy (who also rejects both representational accounts of images and postmodern alternative positions such a Baudrillard's), ${ }^{49}$ Schelling does not refer the image to a totally different, "sacred" realm of reality. The image is the place where the absolute is not above and beyond reality, but rather in it or within it.

Likewise, what we gain in thinking in terms of the absolute, is distance. The perspective of the absolute enables us, not only to look at things from a certain distance, but also to look at our own "looking" and responses from a distance; to see ourselves and our activities, not as the result of individual, free choices motivated by more or less "evil" intentions, but as manifestations of something else, as symptoms, as a whole, as a logic... which corresponds to the Foucauldian approach we referred to earlier. Thus, from Schelling's perspective, our task, as philosopher-spectators, is to understand and analyse the way in which images mirror totality and the logic underlying this mirroring. Or, in Schelling's words, the task of the philosophy of art is

\footnotetext{
${ }^{46}$ Friedrich Wilhelm Joseph Schelling, Pbilosophie der Kunst, in Ausgewäblte Scbriften, 373-374.

${ }^{47}$ For this very reason it is in the end very confusing to use the notion of God, because that would involve of course analysing the ways in which Schelling is redefining it.

${ }^{48}$ I will not develop this point here to avoid overcomplicating the line of thought. But for Schelling not all works of art present the absolute in the same way. There are the so-called different potencies (Potenzen)

${ }^{49}$ Jean-Luc Nancy, The Ground of the Image.
} 
to construe first of all not art as art, as this particular, but rather the universe in the form of art, and the philosophy of art is the science of the All in the form or potence of art. Not until we have taken this step do we elevate ourselves regarding this science to the level of an absolute science of art. ${ }^{50}$

$[\ldots]$

The task of the philosophy of art is thus to present the real element inherent in art in the ideal medium ${ }^{51}$

By "ideal medium," Schelling means concepts. In other words, the task of philosophy is to understand through concepts the very same totality that the images incorporate. Both philosophy and art (images) are expressions or forms of being of the same totality. Thus, it is never a question of whether they refer to or are "true" to what we call "reality," but instead of understanding which aspect and in which way they express something undeniably true about the world (and of understanding how they de facto construct the world). But this means also that images will always show us something about ourselves, that we can always learn something about ourselves from images, i.e. about ourselves as belonging to a totality or a whole. For this world or totality is also the world we inhabit, the totality that constitutes us, the totality that we are.

To come back to the problem of censorship: to the extent that images always "refer," not to specific objects represented, but to the totality or the system that produces them, as the ground of their meaning or content, censored images must also be analysed in terms of the totality that they mirror. When an image is censored, it is thus never a particular content that is being censored, but rather the whole of totality, i.e. the very system that produced that particular image. To censor an image is to negate the reality that such an image presupposes as a whole. Or to be more precise: it is never the nudity, sexual content, or the violence in the image that is shocking and provokes censorship, but rather the "totality" or the "world" that the mere existence of such an image implies. Image-censorship is a negation and rejection of a world in which "we" (as spectators/censors) could co-exist with the world that is mirrored in the image, that is to say: it is a negation of a possibility of being different than how "we" think we are or how "we" want to be. And this means that what is exposed in acts of censorship is a fundamental inability to understand the image, to make sense of it, and accept it as being a mirror of totality and ourselves. In the cases discussed above, one would thus need to say that Facebook's censorship of images of women breastfeeding and/or images of women's mastectomy scars is an attempt to negate a world in which women's breasts could be anything else than what they appear to be in all other nude or semi-nude images that are not censored, namely an object of (male) desire and consumption.

As was just stated above: to censor an image is to negate the reality that such an image presupposes as a whole, and this necessarily includes the censors themselves and their complicity with or belonging to that very "whole." In effect, drawing on Schelling's image-analysis, we can say that image-censorship not only exposes a desire to redefine, shape or influence our understanding of the world/totality, which the image always already mirrors, but also and as a direct consequence of the former: image-censorship is always an act of self-censorship and self-negation. Image-censorship always betrays a desire to negate the insight that what that image shows is part of who we are and the reality we inhabit.

\footnotetext{
${ }^{50}$ Friedrich Wilhelm Joseph Schelling, Philosophie der Kunst, 368.

51 Ibid., 364.
} 


\section{Conclusion}

Schelling's theory of art offers us a non-representational theory of images, which takes its starting point from the infinite activity of self-affirmation on the part of the absolute. In this way, as pointed out earlier, Schelling enables us to contest the postmodern belief that we are living in a "hyperreality," where truths and lies are indistinguishable, where there are no 'true' events and images are meaningless. But he does so without having to give up on the insight that our relation to the world is mediated (through images), and that images are not mere copies of reality, but are as real as anything else. What is more: Schelling's theory and his particular way of understanding the 'absolute' (as an eternal activity of self-affirmation) also enables us to address or understand in a different light what has been described above as the massive proliferation and oversaturation of images that we live in. Indeed, from a Schellingian point of view this "proliferation" and "oversaturation" is not the result of us being subjected or alienated through the development of technology, but responds to a need that is intrinsic to our being, to our very existence, namely our desire and need for self-affirmation.

More importantly, though, the aim of this paper has been to open the possibility of thinking differently about what is going on when social platforms, such as Facebook, censor images. I have tried to show that any attempt to understand this in terms of freedom of speech misses the point. Instead I have argued, following Schelling's thoughts with a somewhat Nietzschean twist, that our task as philosophers is to understand that everything that exists including images - is the expression of a certain form of life and its own need for self-affirmation. Thus, what is being censored is never a particular content, but a certain form of life and self-affirmation, which in the end means that to censor an image is to censor an entire way of being, seeing and understanding the world that somehow clashes with the "reality" that governments, "the media," particular individuals or groups are consciously or unconsciously trying to consolidate. Image-censorship does not threaten freedom of speech alone, it literally negates forms of existence that challenge, question or refute the "reality" that is constantly being constructed and reshaped. The cases I have discussed above most definitely belong to those cases in which censorship is aimed at maintaining a specific patriarchal symbolic order.

Returning to our initial question regarding the violence of the image and the claim that what is violent is not so much the image itself as the reactions it can "provoke," I would now add that this is because images force us to understand ourselves and the world in ways that are often very upsetting and disturbing. Image-censorship is just a rejection of such a revelation.

\section{Acknowledgements}

Thanks are due to David Jay for his kind permission to share the photographs from his SCAR project.

\section{References}

Ash, Timothy Garton. Free Speech: Ten Principles for a Connected World. London: Atlantic Books, 2016.

Baker Martin, \& Petley, Julian. III Effects: The Media/Violence Debate. London: Routledge, 2001.

Baudrillard, Jean. Simulacres et Simulation. Paris: Galilée, 1981.

Calvert, Clay \& Torres, Mirelis. "Staring Death in the face During Times of War: When Ethics, Law, and Self-Censorship in the News Media Hide the Morbidity of Authenticity." Notre Dame Journal of Law, Ethics \& Public Policy 25/1 (2012): 87-122. 
Campion, Darren. "The Morals of Vision: Susan Sontag's "On Photography" Revisited." (June 13, 2017). https://darrencampion.com/2017/06/13/the-morals-of-vision-susansontags-on-photography-revisited-part-1/\#_ednref1 (accessed March 5, 2019).

Didi-Huberman, Georges. Ce que nous voyons, ce qui nous regarde. Paris: Les éditions de minuit, 1992.

Foucault, Michel. L'ordre du discours. Paris : Gallimard, 1971.

Fuery, Patrick \& Fuery, Kelly. Visual Culture and Critical Theory. London: Arnold Publisher, 2013.

Fukuyama, Francis. "Platform or Publisher? Social Media and Censorship." The American Interest (August 8, 2018). https://www.the-american-interest.com/2018/08/08/social-media-and-censorship/ (accessed April 7, 2019).

Höchli, Marc. The Invisible Scissors: Media Freedom and Censorship in Switzerland. Bern: Peter Lang, 2010.

Koch, Gertrud. "Image Politics: The Monotheistic Prohibition of Images and its Afterlife in Political Aesthetics." Critical horizons 14/3 (2013): 341-354.

Mirzoeff, Nicholas. An Introduction to Visual Culture. London/New York : Routledge, 1999.

Mondzain, Marie-José. L'image peut-elle tuer? Paris: Bayard, 2002.

Nancy, Jean-Luc. The Ground of the Image. New York: Fordham University Press, 2005.

Rancière, Jacques. Dissensus. On Politics and Aesthetics, Translated by Steven Corcoran. London and New York: Continuum, 2010.

Schelling, Friedrich Wilhelm Joseph. Philosophie der Kunst. In Ausgewäblte Schriften, Band. 2. Frankfurt am Main: Suhrkamp, 1985.

Sontag, Susan. "Looking at War." The New Yorker (December 2002). https://www.newyorker.com/magazine/2002/12/09/looking-at-war (accessed April 7, 2019).

On Photography. New York: Picador, 1973.

Scruton, Roger. "Photography and Representation." Critical Inquiry 7/3 (1981): 577-603.

Ward, David V. "Philosophical Issues in Censorship and Intellectual Freedom." Library Trends 39/1-2 (1990): 83-91.

Wright, R. George. "Self-censorship and the Constriction of Thought and Discussion under Modern Communications technologies." Notre Dame Journal of Law, Ethics \& Public Policy 25 (2011): 123-142. 


\title{
Alexander Baumgarten and the Violence of the Image
}

\author{
Herman Siemens \\ Institute for Philosophy, Leiden University, \\ The Netherlands
}

\begin{abstract}
This paper draws on Alexander Baumgarten, the founder of modern aesthetics (17141762), to tackle two fundamental questions: What is an image or representation "of violence"? And what makes an image violent, in the sense that it can provoke acts of political violence? In the mediatized environment we inhabit, I argue, our perception has become damaged by generalized logics of image-exchange and-sharing, so that we have become immunized against perceiving concrete particularity. Baumgarten's notion of clear and "con-fused" or "fused" ("verworren") representations describes well how certain images - "violent" images - can break through these mediatized logics and capture the concrete particular in its qualitative singularity. The complexity and plurivocity of such images defeat our cognitive capacity to determine truth/ untruth univocally, provoking a fear of ambiguity, which is one of the small beginnings of violent political acts and events.
\end{abstract}

Keywords: Alexander Baumgarten; Aesthetics; Ambiguity; Fiction; Image; Media; Perception; Political Violence; Representation.

\section{Introduction}

This paper, like almost all the other contributions to this issue, was written in the course of a three year project involving participants from nine international research centres entitled Towards a political ontology of violence: reality, image and perception..$^{1}$ The aim of the project was to study how acts of violence and their representation in the media are impacting on democratic politics both within and outside Europe, by combining a political ontology of violence with an aesthetics of the image. In this paper, I would like to tackle a fundamental question for any attempt to understand and describe the relation of images to violence. What kind of vocabulary best enables us to describe the power (some) images have to affect us in ways that words / discourse cannot? What kind of philosophical vocabulary is best suited to describing images, and their otherness to discourse? I am asking how to conceptualise images, as a preliminary to asking about images of violence and the violence of the image. This question does force possibly distort - the issue, since the images in circulation are (almost) all accompanied and framed by words. But by forcing the issue I aim to get at the specificity of the image, and to address head-on the tension between thought and image in thinking about images.

\footnotetext{
${ }^{1}$ For a more detailed description of the project, please see the Foreword. The only contribution that was not initially part of the project is the interview with the philosopher Mathieu Triclot on violence and video games.
} 


\section{Desiderata}

There are, I propose, at least four desiderata for a philosophical vocabulary that could describe the specificity of the image and its relation to violence.

1. It should be a vocabulary that can show how images (unlike words or speech) resist conceptual analysis - a vocabulary for the non-conceptual character and logic of images.

2. It should be vocabulary that links the perception and creation of images to the body, specifically the partiality of a body damaged by violence.

3. It should be a non-representational vocabulary that resists the naive realist answer to the question of the image of violence, as re-presenting violence in reality, and its presupposition in the subject - object opposition. One which instead acknowledges that images create a "world" that, while fictional, has a unique capacity to reveal underlying structures and relations that remain opaque to empirical experience. The desideratum is, then, to treat the question of the "image of violence" as a creatum, not a mimesis-datum.

4. Finally it should be a vocabulary that can show how the perception of images has the capacity to unsettle and change the ways in which we perceive things around us. In this paper I take seriously the claim that in our media-saturated environment (Baudrillard), we have become immune to images, or to put it differently: that our perception of the world is damaged (beschädigt) ${ }^{2}$; that damaged perception is the norm, but that certain images can break through our mediatized immunity and influence our perception and action. These then are the images that can have political consequences or provoke the reactions we need to study in the project. The proposal here is to pose the question of the "violence of (certain) images" against the general background of damaged perception.

The thesis of this paper is that Alexander Baumgarten (1714-1762), the founder of modern aesthetics, offers conceptual tools for thinking about images that go a long way to addressing these desiderata.

\section{Why Baumgarten?}

There are certainly reasons for not choosing Baumgarten as a guide through our world of mediated violence. For one, his account of perception is situated in the coincidence of logic and ontology of Leibniz's best of all possible worlds, and oriented towards harmony and perfection. Violence is, to say the least, contradiction, even real contradiction or opposition in Kant's sense, and has no place there; nor does a critical-historical account of damaged perception. On the other hand, the main impulse behind Baumgarten's aesthetic science or science of sensate knowledge (Ästhetik, Wissenschaft der sinnlichen Erkenntnis) was to emancipate our sensibility from the curse of confusion, error and vice placed upon it since Plato and from what he calls the "tyranny" of the understanding and reason advanced by rationalism (Aesthetica 12). ${ }^{3}$ In order to rehabilitate sensibility, he developed a conceptual vocabulary designed to re-describe the non-conceptual character of our sensible capacities in positive terms - a

\footnotetext{
${ }^{2}$ Heinz Paetzold, Ästhetik des deutschen Idealismus (Wiesbaden: Steiner, 1983), 53ff.

3 Alexander Baumgarten, Ästhetik 1. \& 2. Teil, Lateinisch- Deutsch. Übersetzt, mit einer Einführung, Anmerkungen und Registern hrsg. von Dagmar Mirbach. (Hamburg: Felix Meiner, 2007). Henceforth Aesth.
} 
vocabulary that would do justice to the qualitatively distinct nature of our sensate representations and the logic of sensations, and thereby secure a kind insight and knowledge for sensibility that is sui generis: unique and irreducible to conceptual knowledge - what he calls "cognitio sensitive" or the "analogon rationis." It is this vocabulary that I want to present, with the question of whether it can be set loose from its metaphysical moorings in Leibniz's best of all possible worlds and made fruitful for describing the power of certain images against the contemporary problem-background of generalized immunity and damaged perception.

Baumgarten is important because he shifts the focus in rationalism on representations to the relations we have with our presentations. Beauty resides not so much in the representation of perfection (Wolff), but in the ways we exploit its possibilities with our sensory-imaginativecreative capacities. As I will try to show, Baumgarten is a profoundly relational thinker, who opens up the space of our perceptual-creative relation with images to thought.

But there is another reason for not choosing Baumgarten as a guide to our mediatized environment. His Ästhetik aims to show how our sensate capacities for insight into the order of things are activated in the mode of the beautiful, as that which takes place in art in general. Yet his vocabulary is oriented almost exclusively to poetry, as are the examples on which he draws, not the plastic arts. I can only express my astonishment that neither he nor anyone else I have come across share my intuition that his vocabulary is eminently suited to picking out features specific to images, rather than poetry, and to our perception of images in ways that address the desiderata set out above. It is not, therefore, without a certain violence, a hermeneutic violence, that I will make my case.

\section{Towards an aesthetics of the image}

\section{A. The Non-Conceptual Character of the Image}

The first desideratum was for a vocabulary that describes the non-conceptual character and logic of images. There are several key concepts in Baumgarten for describing the qualities of our sensate representation: richness or plenitude (Fülle, Reichtum, venusta, ubertas); liveliness (Lebendigkeit, vividitas); complexity; singularity; aesthetic determination; and the logic of the individual. There is also a range of sensate capacities he ascribes to us, including: (1) wit (Witr, ingenium sensitivum): the capacity to see the agreements among things (die Übereinstimmungen der Dinge einzusehen), and (2) perspicacity (Scharfsinnigkeit, acumen sensitivum): the capacity to recognise the differences between things (die Verschiedenheiten der Dinge zu erkennen), and the conjugation of ingenium and acumen in what he variously calls "taste in the broader sense" (Geschmack in der weiteren Bedeutung, gustus significatu layiori, sapor, palatum, nasus), or "sensate judgement-power" (sinnliches Beurtheilungsvermögen, facultas diiudicandi), or "the lower judge" (der untere Richter, iudex inferior), or "judgement of the senses" (iudicium sensuum). But let me begin with the central concept: that of confused or fused (verworren, confusus) representation.

This term is inherited from Leibniz, who criticized Descartes for restricting knowledge to clear and distinct representations and proposed instead a graduated account of knowledge in terms of degrees, and new criteria for distinguishing them. For Leibniz, as for Baumgarten, the question of knowledge is posed in terms of composite things (zusammengesetzte dinge). Knowledge is knowledge of composite things. Composite things are conceived as wholes composed of different parts (marks, merkmale, notae). The parts in turn are conceived as wholes composed of different parts (marks, merkmale, notae) as far as limit-case: parts that are simple, non-composite, primitive or basic. Knowledge, then, consists of the analysis of the concepts of things, that is, the listing of parts (and parts of parts etc.) of things conceived or represented, that is, subsuming the parts under concepts from lower to higher-order concepts, 
until (at ideal end of analysis) one reaches simple concepts and statements of identity: "primitives" (see fig. 1.).

LEIBNIZ: degrees of knowledge (source: Meditotions on Knowiedge, Truth, ond toe os)

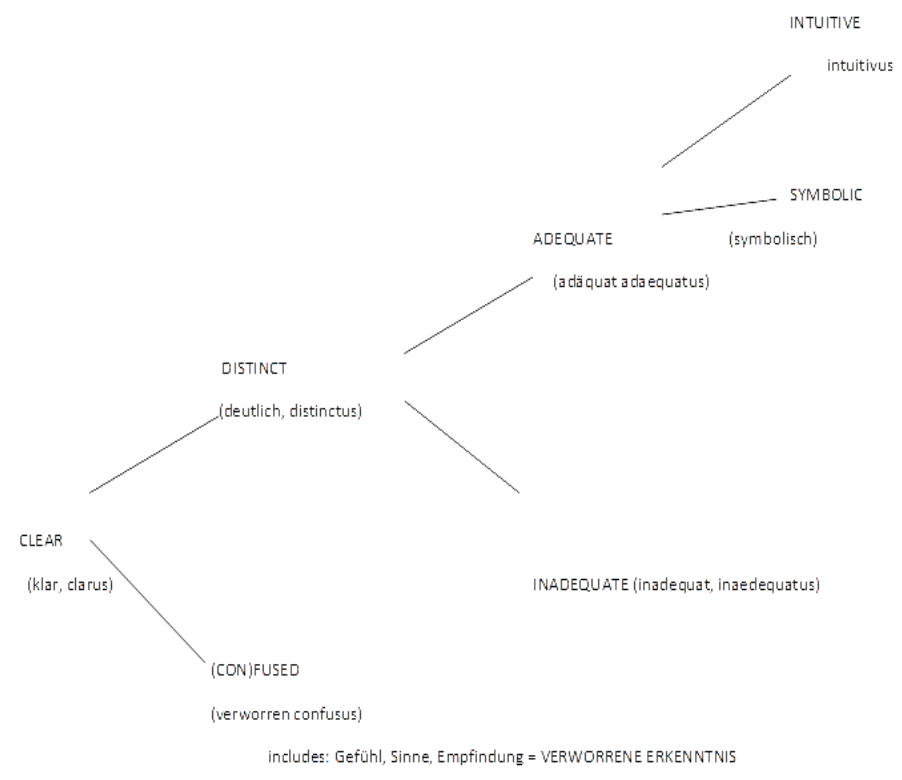

OBsCURE (dunkel, obscurus)

Fig. 1. Degrees of Knowledge in Leibniz

obscure notion $=$ insufficient for re-cognizing $\&$ distinguishing the thing that it represents from other things

clear notion $=$ gives us the means for re-cognizing $\&$ distinguishing the thing that is represented from other things

clear \& (con)fused = we cannot list, one by one, the marks that are sufficient to distinguish thing represented from others:

non-analysable

clear $\&$ distinct $=$ we can list all marks sufficient to distinguish thing represented fr others, i.e. to give nominal definition:

analysable/defineable

distinct \& inadequate = we can list individual marks sufficient to distinguish the thing reresented $\mathrm{fr}$ others, but cannot list all marks of individual marks (not defineable)

distinct $\&$ adequate $=$ we can list individual marks sufficient to distinguish the thing represented from others and all the marks of the individual marks (complete analysis) 
On this schema, a clear and distinct representation is one for which all marks sufficient to distinguish the thing represented from others can be listed, i.e. one can give a nominal definition. But Leibniz also acknowledges as a degree of knowledge representations that are clear and confused. By this he means presentations that fall below the threshold of conceptual analysis: we cannot list, one by one, the marks that are sufficient to distinguish the thing represented from others, yet the representation is still clear because we can still re-cognize and distinguish the thing represented from other things at a sensate level:

$[\ldots]$ and so we recognize colours, smells, tastes, and other particular objects of the senses clearly enough to be able to distinguish them from one another, but only through the simple testimony of the senses, not by way of marks that we could list. [...] Similarly, we see that painters and other skilled craftsmen can accurately tell well-done work from what is poorly done, though often they can't explain their judgments, and when asked about them all they can say is that the works that displease them lack a certain je-ne-sais-quoi. ${ }^{4}$

An obscure (that is, un-clear) perception is one that is not sufficient for recognizing the thing that it represents e.g. of a certain flower, which, when I try to recall it, cannot be sufficiently recognized, i.e. distinguished from other nearby flowers. Obscure representations fall below the threshold of apperception or self-conscious awareness, as do clear and confused representation, so that Leibniz leaves space for degrees of knowledge below the level of conscious self-awareness, understood as perceptions without apperception.

Leibniz, then, ascribes cognitive value to perceptions that resist conceptual analysis and subsumption and fall below self-conscious awareness, yet can be recalled or re-cognized as distinct unities and can serve us to make qualitative judgements (without grounds: je-ne-saisquor) concerning (the quality of) what they represent - all at the level of sensation. The implication is that sensibility houses pre-conceptual resources for synthesis and discrimination, as well as for judgement.

These cues are taken up and developed by Baumgarten, for whom clear and confused perceptions lie at the core of sensate knowledge (see fig. 2). As an example of clear and confused perceptions, Baumgarten describes the way colours merge or flow into one another to give an overall impression, which can be recalled and re-cognized as such again. As an example of obscure perceptions, he gives the sound of single wave in a thunderous surge, which could never be recognized as such again. Of particular interest for my argument is (a.) the way Baumgarten reinterprets the notion of "con-fusion" (Verworrenheit), so as to give it a new, positive meaning, and (b.) the way he extends Leibniz's notion of clarity by distinguishing "intensive" from "extensive" clarity.

\footnotetext{
${ }^{4}$ Gottfried Wilhelm Leibniz, Meditations on Knowledge, Truth and Ideas (transl. Jonathan Bennet), 2, https://www.earlymoderntexts.com/assets/pdfs/leibniz1684.pdf (accessed 20.05.2019). Translation modified by author.
} 
BAUMGARTEN

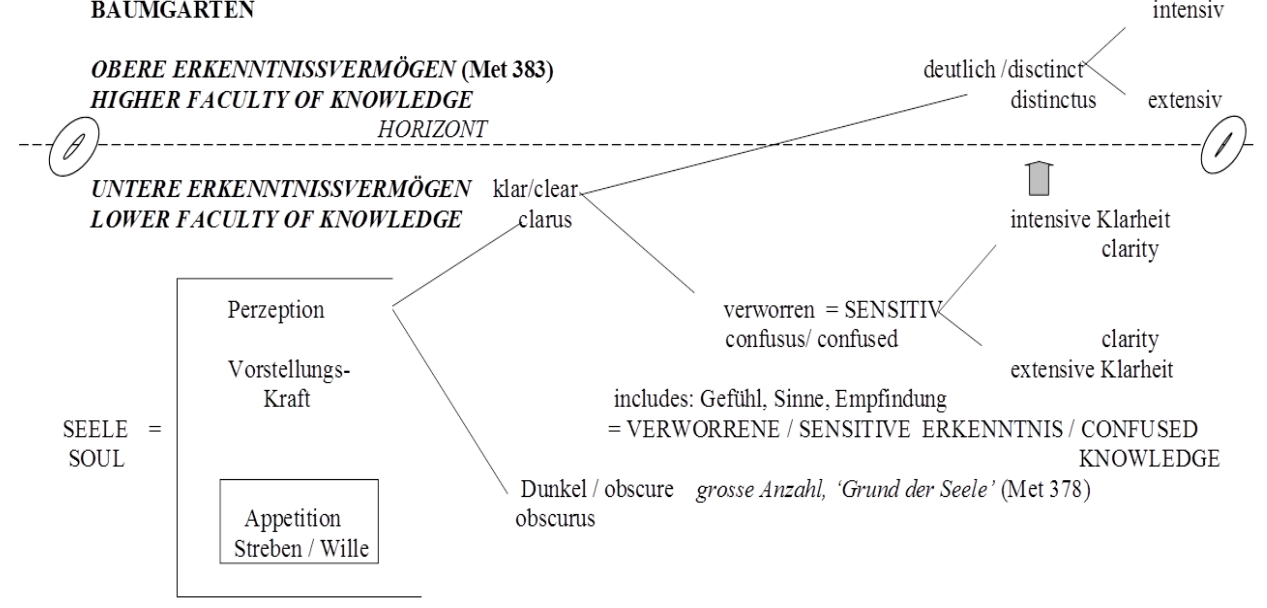

dunkel = representation not distinguishable, not re-cognizable e.g. sound of single wave in a thunderous surge (cf. Med 12) klar = representation distinguishable and re-cognizable (memory) (Med. 12), insofar as it is

verworren $=$ indivdual marks cannot be listed, e.g. clours flowing into one another as parts of an overall impression deutlich $=$ individual marks can be conceptually listed

(Med 15)

intensive Klarheit: distinctness of marks (Med 16; Met 393); intellectual; whole is lost extensive Klarheit: number of marks (Med 16; Met 393) whole is clear; inner plentitude / inhaltliche Fülle (Aesth $§ 559 ; 619$ )

Fig. 2. Sensate Knowledge in Baumgarten (below the Horizont)

(a.) In the Meditationes, Baumgarten's first text on aesthetics, he writes:

Confusus: what is meant is that the individual marks [i.e. features / parts] of a representation fuse [verschmelzen] in an intuitive overall image [Gesamtbild] (which is the case in every sensate perception). (Meditationes 15) ${ }^{5}$

In other words: "confusion" no longer means that which is incapable of conceptual analysis, confuses rational understanding and is therefore the source of error (confusio mater erroris). Rather, it describes the way sensate perceptions cannot be broken down into constitutive elements, but instead constitute relational wholes. Transposed onto the plane of images, we might say: "Con-fusion" describes the way images are perceived as relational wholes, where the whole is a complex of relations, which cannot be resolved into their relata as the elements or features that constitute the whole image. The relata or elements remain obscure, indiscernible and insignificant, and the only whole we perceive is the image as a complex of significant relations.

(b.) Building on the concept of a relational whole, Baumgarten then extends the notion of clarity in the direction of increasing complexity or inner plurality. With "intensive clarity" Baumgarten designates the transition or transformation of sensate to conceptual knowledge (Verstandeserkenntnis) achieved by focusing our attention on the individual elements or relata

5 Alexander Baumgarten, Meditationes philosophicae de nonnullis ad poema pertinentibus = Philosophische Betrachtungen uber einige Bedingungen des Gedichtes (Lateinisch-Deutsch / ubers. und mit einer Einl. hrsg. von Heinz Paetzold, Hamburg: Felix Meiner, 1983); henceforth Med. Translated by author. 
in succession and analyzing them into their constituent elements etc. The gain in "depth" of understanding is accompanied by a loss, which Baumgarten places under the heading of "abstraction": to focus our (limited) attention on one mark, then another, is to cast everything else into obscurity, and the first victim of discursive analysis is the whole, the relational whole that is - or was - the image of perception: we lose the image in analyzing it.

With "extensive clarity," Baumgarten means the opposed directionality: increasing complexity, increasing differentiation by way of a greater plurality of marks. Perceptions with extensive clarity are characterized by richness or plenitude (Fülle, Reichtum, venusta, ubertas); but also by liveliness (Lebhaftigkeit, vividitas) (Metaphysica 393) ${ }^{6}$, and in the Aesthetica 619, Baumgarten makes it clear that he has a dynamic multiplicity of relations in mind:

I therefore believe I can rightly call those thoughts lively in which a special diversity and as it were a rapidly succeeding change of marks, pressing each other reciprocally, can be perceived. And from which, in their exceptional con-fusion, that radiance and luminescence of thought in particulars arises, which must nonetheless remain transparent and absolutely clear in its wholeness.

(Aesth 619)

Darum glaube ich mit vollem recht jene gedanken lebhaft nennen zu können, in denen eine besondere verschiedenheit und gleichsam ein rasch erfolgender wechsel der sich gegenseitig bedrängenden merkmalen wahrgenommen wird, aus deren außerordentlicher verwirrung jener glanz und jenes leuchten des denkens im einzelnen entspringt, das doch in seiner gesamtheit durchsichtig und absolut klar sein muß.

Reading this as a statement about image-perception / creation, I would suggest that certain images have this character: the image as a dynamic complex of shifting relations that remains all the while an identifiable whole; a plenitude (venusta) or excess of relations that press and pressurise one another (bedrängen), generating what Baumgarten calls "the infinitely many meanings of such an object that is almost incomparable in its way" (Aesth 561).

At the heart of sensate knowledge is a concern with the concrete particular in its qualitative singularity, understood as a plurality of shifting relations and meanings. This requires a complete re-orientation, a reversal of the directionality of thought from the logic of the universal, driven by the understanding and the operations of analysis and subsumption, to what Baumgarten calls the logic of the individual (see fig. 3).

This re-orientation can be seen clearly in Baumgarten's concept of sensation (Empfindung), marked by pluralizing (Merkmalfülle), concretizing and synthesizing functions, which allow for a focus on the individual qua particular, so as to give it its "maximal determination" (Bestimmung). The same can, I suggest, be said of the logic of images, or at least: of certain "violent" images. Baumgarten's logic of the individual was conceived in opposition to the hegemony of conceptual knowledge and the logic of the universal in rationalism. When set against the contemporary problem-background of generalized immunity to the image, it suggests that the logic of individual has been overrun by generalized logics of image-exchange and sharing in our mediatized environment, and that our immunity is precisely our incapacity to perceive the concrete particular in the image. But it also suggests that certain images, "violent images", have the power to return the concrete particular to our damaged perception.

\footnotetext{
${ }^{6}$ Alexander Baumgarten, Metaphysica / Metaphysik (Historisch-kritische Ausgabe, G. Gawlick and L. Kreimendahl transl., intro. and ed.s, Stuttgart: Fromann-Holzboog, 2011). Henceforth Met.
} 


\section{MODELS OF RATIONALITY:}

\section{* OBERE ERKENNTNISVERMÖGEN / HIGHER FACULTY OF KNOWLEDGE}

ORGANON = Verstand / understanding (intellectus)

Logik des Allgemeinen / logic of the universal via: subsumption of manifold \& abstraction from qualitative singularity

TELOS: the universal \& simple

\section{* UNTERE ERKENNTNISVERMÖGEN / LOWER FACULTY OF KNOWLEDGE}

(Met 468(640) and: 426, 428, 432, 438, 451, 452, 455, 459)

ORGANON = das Vernunftähnliche / analogue of reason (analogon rationis). Vermögen, die Verbindungen der Dinge undeutlich zu erkennen:

Capacity to know the relations of things indistinctly:

Logik der Konkretion / logic of concretion or of the individual

TELOS: the specific, singular, the concrete and complex (composite / zusammengesetzt) $=$ to grasp singularia in fullest possible determination: qualitative uniqueness $=$ complexity

Fig. 3. The Two Models of Rationality in Baumgarten

The best formulation of this thought is in Aesthetica 559, where Baumgarten speaks of "the unlimited plenitude [Fïlle] of significant particulars" in every "individual appearance", of the "numberless marks of endless differences" that can be thought if we really know things as individual appearances, and of the losses incurred by the logic of the universal, when it abstracts from the individual in its singularity. Baumgarten then gives an extraordinary list of qualities in the individual that are lost to the understanding in abstraction:

1) that which is in greater plenitude than belongs to a complete representation,

2) that which in greatness and significance points beyond the level presupposed when knowledge reaches its object,

3) whose truth and untruth cannot be sufficiently clarified through determinate exact science, such that nothing false in knowledge remains,

4) that which does not necessarily belong to distinction [Unterscheidung] and so withdraws from clarification by a specific subject

5) that which for just this subject is not completely certain and not strictly demonstrable, where the fear of the opposite is not yet controlled,

6) that which could lead to an opposed supposition, could hinder our assent and perhaps even evoke loathing (Abscheu ${ }^{7}$, taedium) (Aesth 559)

\footnotetext{
7 Schweizer translates "taedium" with Abscheu, which ranges in meaning from loathing to revulsion, disgust, horror. See Alexander Baumgarten, Theoretische Ästhetik: die grundlegenden Abschnitte aus der "Aesthetica" (1750/58) (Lateinisch-Deutsch, übers. und hrsg. (transl. and ed.) Hans Rudolf Schweizer, Hamburg: Meiner, 1983). Mirbach (see note 3) opts for the blander Unlust or displeasure.
} 
1) was in grösserer Fülle vorbanden ist, als zu einer vollständigen Vorstellung gehört, 2) was an Größe und Wichtigkeit über die Stufe hinauswest, die in der Erkenntnis vorausgesetzt ist, welche ibr Objekt erreicht, 3) dessen Wahrheit oder Unwabrheit durch eine bestimmte exacte Erkenntnis nicht genügend erklärt werden kann, und zwar damit nichts Falsches in der Erkenntnis zurückbleibe, 4) was nicht notwendig zur Unterscheidung gebört und ebenso, was sich der Klärung durch ein bestimmtes Subjekt entziebt, 5) was für eben dieses Subjekt nicht vollständig gewiß und nicht streng beweisbar ist, wo die Furcht vor dem Gegenteil noch nicht gebannt ist, 6) was zu einer gegenteiligen Annahme führen, unsre Zustimmung verbindern und vielleicht sogar Abscheu hervorrufen könnte.

There is an unmistakable shift in these lines from qualities of sensate representations to the subject. Or, reading it as a phenomenology of image-perception: from the qualities of the image to the subject. The movement is from the way the image exceeds its own boundaries ("greater plenitude than belongs to a complete representation"); from the image, whose meanings exceed the bounds of conceptual subsumption, whose truth / untruth exceeds determination by exact science, and whose relations exceed our capacity for analysis - a movement from these qualities of the image, to what confronts the subject with his fear of error, defies affirmation, and ultimately provokes horror or disgust (Abscheu). In the context of our generalized immunity to the image, I want to suggest that Baumgarten here gives us a compelling phenomenology of "violent" images, and their impact on us. As sensate images of particulars, their radical indeterminacy provokes fear in us: fear concerning the undecidability of truth/untruth - of our incapacity to determine whether something is true / untrue. In short: fear of ambiguity. We therefore negate and reject these images with bodily disgust. And perhaps this disgust of indeterminacy is one of the "the small beginnings" of political acts and events. $^{8}$

\section{B. Heterocosmic fictions}

All of this raises the question of representation: if sensate knowledge is knowledge of things as concrete particulars, if images are images of concrete particulars, what is the status of those things? What, in the final analysis, is an image of violence? The short answer for Baumgarten is: their status is imaginary or fictional.

The third desideratum was for a non-representational vocabulary that breaks with the subject-object opposition and the assumption of an independently existing order of things, which is the source, the explanans and the measure of representational content. On the other hand, doing justice to the violence of certain images requires that we keep open the question of the image and reality. Violent images are precisely those images of sensuous particulars that break through the mediatized logics of image-sharing and-exchange, and can impact on our damaged perception - with disgust. I think Baumgarten may help us to understand this better.

\footnotetext{
${ }^{8}$ On intolerance of ambiguity and the need for cognitive closure in social psychology, see e.g. Jim Sidanius "Intolerance of ambiguity and socio-politico ideology: a multidimensional analysis." European Journal of Social Psychology 8 (1978): 215-235; Else Frenkel-Brunswik "Intolerance of Ambiguity as an Emotional and Perceptual Personality Variable."Journal of Personality 8/1 (1949): 108-143; D.M. Webster and A.W. Kruglanski, "Individual differences in need for cognitive closure." Journal of Personality and Social Psychology, 67 (1994): 1049-62; Jeff Victoroff and Janice Adelman, "Why Do Individuals Resort to Political Violence? Approaches to the Psychology of Terrorism," in The Ashgate Research Companion to Political Violence, ed. Marie Breen-Smyth, Marie (London: Routledge, 2012 [20160323. VitalBook file]). According to Victoroff and Adelman "[]ittle systematic research has explored possible links between cognitive style and political violence."
} 
Baumgarten's commitment to Leibniz's best of all possible worlds means that there is an objective order of things (Zusammenhang der Dinge, nexus rerum) to be known. It is to be known, not by re-presenting objects empirically, but by unravelling that same order that lies darkly in each of us (Leibniz's micrcosmos), in the domain of obscure (non-clear) representations that Baumgarten calls the "field [Feld] of darkness" or "the ground of the soul". But how can "the order of things" be re-presented out of the disorder (resistance to conceptual understanding) that defines the field of darkness? Baumgarten's answer is: through the creation of heterocosmic fictions.

Baumgarten's Ästhetik is primarily a production aesthetics that aspires to understand better the nature or physis of the artist or "aestheticus", in order to guide it towards beauty and (aesthetic) truth. Leibniz's vis activa become vis creativa, differentiated into a range of capacities or "natural dispositions" (see fig. 4).

Of central importance for both the Metaphysica and the Aesthetica are the imagination (Einbildungskraft, Phantasie, phantasia) and poetic disposition (Dichtungsvermögen, Dichtungskraft, facultas fingiendi). Together they draw on sensations, memory and the obscure representations on the ground of the soul to create a "new world": a world that is impossible in our world (since it follows different laws), but is not absolutely impossible in the sense that it is non-contradictory, or put more loosely: coherent. Such worlds are the product of the capacity for non-conceptual synthesis, which Baumgarten ascribes to sensibility or the "lower capacity for knowledge". A heterocosmic fiction - Baumgarten's term - is not a mimesis or re-presentation of the objective order of things; at most, it is a mimesis of the creative principle of nature, natura naturans or what Baumgarten calls "the inner principle of change in the universe" (Med 110). As such, the artist enjoys full creative freedom to create a "new" world according to laws and principles (form) of his own devising, an entirely other order of things. And in this way, Baumgarten argues, the artist can exhibit in a sensate manner insights into the order of things that escape our everyday perception. The paradox of fiction - in Baumgarten's thought - is that the underlying connection of things in reality (nexus rerum), often inaccessible at the phenomenal level, can be better understood by constructing a different, possible world (heterocosmos). It is the very otherness of fictional worlds that lend them unique disclosive powers.

In line with the logic of the individual, the task of the heterocosmic artist is, by discriminating and combining images (Einbildungen, phantasmata, imaginationes), to create a world of concrete particulars with maximal extensive clarity, so that we can "behold several things in a representation, which are not contained in many sequences of our representations" (Med 43). For Baumgarten, concrete particulars with maximal extensive clarity of this kind are not normally available to experience, so that they can only be imaged as fictions that "have no locus in this world" (Aesth 511). Fictive images of this kind break through our everyday forms of perception and the connotations they carry, so as to make possible a productive reconstruction of habitual patterns of perception. ${ }^{9}$ One could say: their task is to enhance the (extensive) clarity of our representations without surrendering their sensate plurivocity to our fear of ambiguity and the univocity of the concept.

\footnotetext{
${ }^{9}$ See Heinz Paetzold, Ästhetik, des deutschen Idealismus (Wiesbaden: Steiner, 1983), 44-47.
} 


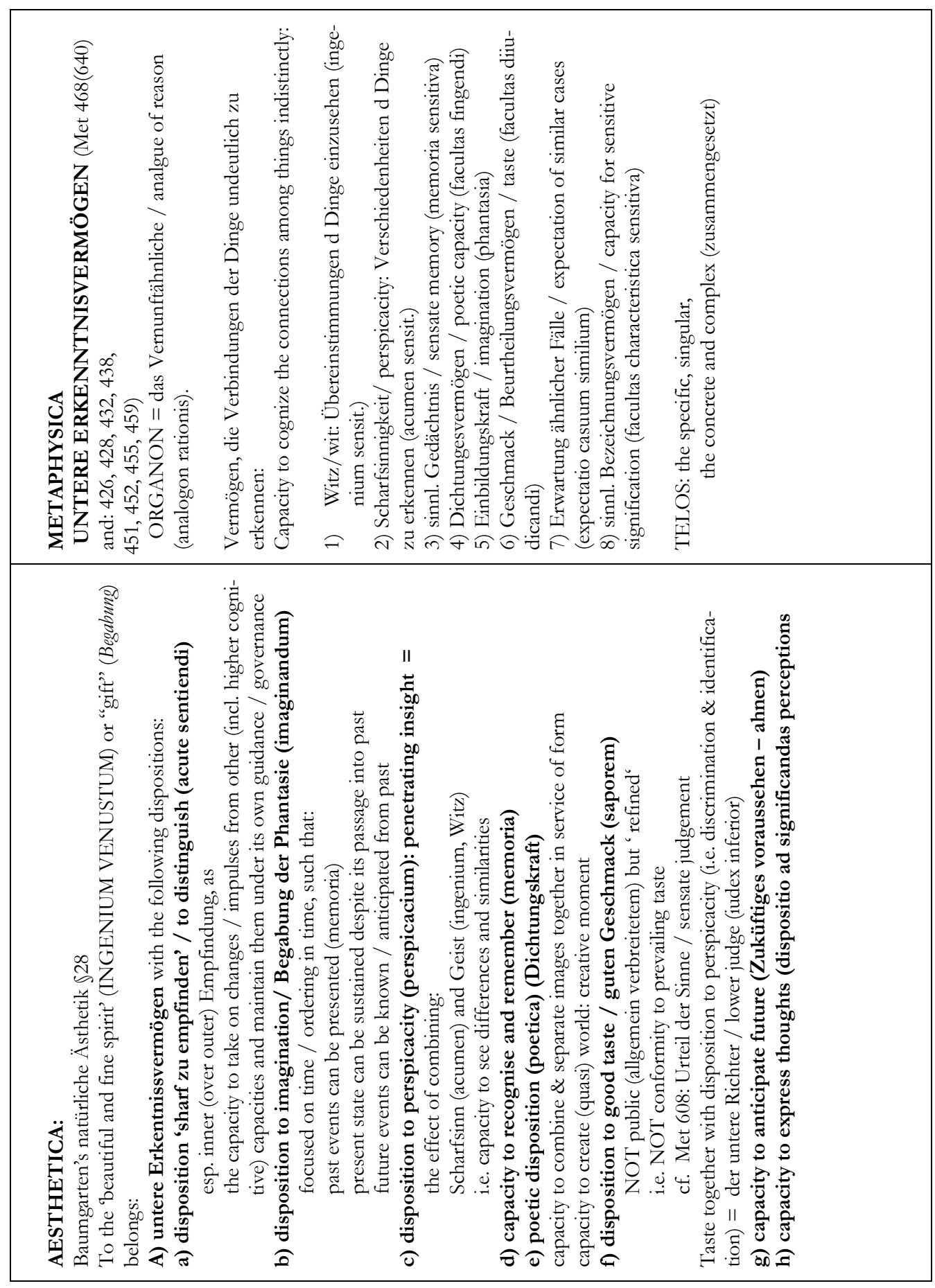

Fig. 4. Sensate creative capacities or dispositions in Baumgarten's Metaphysica and Aesthetica 
At the same time, however, Baumgarten insists that these other-worldly images are not just fictions, but disclose something about things and the relation of things in this world. How can this be? His best answer comes in the form of a requirement or criterion for heterocosmic fictions: not only must they obey the principle of non-contradiction (loosely construed as a criterion of coherence); they must also be "analogous" to reality, even if they are impossible in this world. Whatever exactly he means by "analogy", it seems to compromise his fictionalist aesthetics with the demand that heterocosmic fictions re-present in one way or other the order of things in this, the best of all possible worlds. But what if we replace the moralmetaphysical concept of the best of all possible worlds with the generalized logics of exchange and sharing that characterise our mediatized world? What if Baumgarten's concern with the limits of habitual patterns of perception is radicalized into a critical-historical theory of damaged perception and mediatized immunity? And what if Baumgarten's orientation towards beauty as the sensate representation of the objective order of things (or: perfection) is replaced with an orientation towards violence, as that which breaks or breaks through the mediatized logics of exchange and sharing?

With these questions I am proposing that Baumgarten's fictionalist aesthetics can be bent towards a fictionalist account of images that gives us a vocabulary, a way to think about the violence of certain images and images of violence. The claim is that the "violence of the image" designates those sensate images of particulars, whose complexity and plurivocity ("infinitely many meanings") defeat our cognitive capacity to determine truth/untruth univocally, provoking that fear of ambiguity and disgust that Baumgarten describes so well. Such images dis-locate and disorient us, confronting us with our incapacity to make sense of them, by creating fictional worlds, heterocosmic fictions that stand in a relation of radical dis-analogy to our mediatized environment. By presenting (not re-presenting) the really lived experience of violence in its singularity with maximal extensive clarity, they are also uniquely capable of breaking through generalized logics of image-exchange and -sharing. It is this combination cognitive failure with an insight into the concrete reality of violence obscured by our mediatized environment that can provoke acts of political violence.

\section{Conclusion}

To conclude, I would like to present a synopsis of the argument in a series of propositions and the lines of research needed to realise it as a project:

- Our mediatized environment is characterized by generalized logics of image-exchange and -sharing.

- These logics have damaged our perception such that we have become immune to perceiving concrete particularity (and this includes the really lived experience of violence).

- A "violent image" is one that breaks through our immunity, returns the particular to our sensation and confronts us with it.

- This kind of image is best described as a "con-fused" or "fused" image with extensive clarity à la Baumgarten, that is: a dynamic complex of shifting relations, which cannot be resolved into their relata, but remains all the while an identifiable whole: a preconceptual synthesis.

- Only this kind of image can capture the concrete particular in its qualitative singularity, understood as a plurality of shifting relations and meanings.

- Such images defeat the comfortable standardized images and narratives that immunize us against really lived violence by creating a fictional world (a "heterocosmic fiction") that confronts us the experience of violence in its singularity. 
- Their complexity and plurivocity ("infinitely many meanings") defeat our cognitive capacities to determine truth / untruth univocally and provoke a fear of ambiguity, a feeling of insufficiency or powerlessness that leads to disgust, rejection, dis-location and ultimately - that is my claim - to acts of political violence.

If they are to be of use in understanding the relation of images to violence, these propositions require research along four lines:

1. Research into the logics that characterise our mediatized environment, understood as generalized forms of exchange, sharing, circulation etc. that override the logic of the individual specific to sensate images, and immunize us against perceiving concrete particularity.

2. Related to this: critical-historical research into the ways in which our perception has been damaged in our mediatized environment, such that we have been immunized against images of concrete particularity.

3. Research into the sources or "small beginnings" of political acts of violence in the encounter with "violent images" that break or break through the mediatized logics of exchange and our damaged perception, confronting viewers with their cognitive failure in the face of the "infinitely many meanings" of sensuous particulars, the fear of ambiguity, leading to disgust, rejection and radical dis-location.

4. Research into a non-representational theory of images understood as heterocosmic fictions that stand in relations of dis-analogy to our mediatized environment by creating a world that confronts us with the experience of violence in its singularity.

\section{References}

Baumgarten, Alexander Gottlieb. Meditationes philosopbicae de nonnullis ad poema pertinentibus / Philosophische Betrachtungen uber einige Bedingungen des Gedichtes (Lateinisch-Deutsch), Heinz Paetzold (transl. intro. and ed.), Hamburg: Felix Meiner, 1983.

Theoretische Ästhetik: die grundlegenden Abschnitte aus der "Aesthetica" (1750/58)

(Lateinisch-Deutsch). Translated and edited by Hans Rudolf Schweizer. Hamburg: Meiner, 1983. . Asthetik 1. \& 2. Teil, Lateinisch- Deutsch. Dagmar Mirbach (notes, indices, intro and ed.), Hamburg: Felix Meiner, 2007.

. Metaphysica / Metaphysik, Historisch-kritische Ausgabe, G. Gawlick and L.

Kreimendahl (transl., intro. and ed.s), Stuttgart: Fromann-Holzboog, 2011.

Frenkel-Brunswik, E. "Intolerance of Ambiguity as an Emotional and Perceptual Personality Variable." Journal of Personality 18/1 (1949): 108-143.

Leibniz, Gottfried Wilhelm. Meditations on Knowledge, Truth and Ideas (transl. Jonathan Bennet), https://www.earlymoderntexts.com/assets/pdfs/leibniz1684.pdf (accessed 20.06.2019). Translation modified by author.

Paetzold, Heinz. Ästhetik des deutschen Idealismus, Wiesbaden: Steiner, 1983.

Sidanius, J. "Intolerance of ambiguity and socio-politico ideology: a multidimensional analysis." European Journal of Social Psychology 8 (1978): 215-235.

Webster, D.M. and Kruglanski, A.W. "Individual differences in need for cognitive closure.” Journal of Personality and Social Psychology 67 (1994): 1049-62.

Victoroff, J. and Adelman, J. "Why Do Individuals Resort to Political Violence? Approaches to the Psychology of Terrorism." In The Ashgate Research Companion to Political Violence. Edited by Marie Breen-Smyth. London: Routledge, 2012. 